\title{
USE OF ECONOMIC SANCTIONS BY PRIVATE GROUPS: ILLEGALITY UNDER THE SHERMAN ACT
}

Economic sanctions, or refusals to deal aimed at the isolation of a business from its necessary economic relationships, have traditionally been employed to achieve "good" as well as "bad" purposes. The resulting dilemma for the law is the same as that which arises wherever men have reconciled themselves to using unpleasant types of force in pursuit of a desirable goal. Not only has the boycott been used to drive competitors out of business; it has been turned with vigilante spirit against purveyors of obscene books and magazines, and stores that refuse service to Negroes. In a similar manner, trade associations have set up industry self-regulation programs in attempts to root out substandard goods and practices.

It is natural to hope that the purposes of "beneficent" economic sanctions could be asserted as a justification if such sanctions should involve sufficient interstate commerce to be challenged under the federal antitrust laws. One might at least expect that a rational legal system would balance the good purpose served by such a boycott against the purposes served by the antitrust laws, so as to reach a just result by some form of compromise. This approach to boycott cases has been taken by the common law of torts. ${ }^{1} \mathrm{~A}$ balancing-ofinterests approach to antitrust cases involving concerted refusals to deal would be made difficult by the fact that the courts have enunciated no clear picture of what policy is being served by holding such activity illegal. Among the ways in which concerted refusals to deal have been thought to restrain trade are: (1) the flow of goods is shut off, hence restrained, between the combination and its victim;2 (2) the freedom of action of the parties to the com-

I See RestatemENT, ToRTs $\S 765$ (1938), where a concerted refusal to deal is defined as a tort "if the concerted refusal is not justified under the circumstances." Among factors to be weighed on the issue of justification are "the objects sought to be accomplished and the interests sought to be advanced by the actor's conduct," the appropriateness of the boycott as a means to these ends, "relative economic power" and other relations between perpetrators and victim, the extent of hardship to the victim, and "the effects of the actors' conduct and of its objects on the social interest in business enterprise and competition." Ibid.

Similarly, $\$ 766$ defines the tort of inducing another to refuse to deal with a third party, stating that such actions are tortious unless the person inducing them has "a privilege to do so." Sections 767-74 spell out the circumstances in which such a privilege is present. Section 767 states that the following are important factors in determining if there is a privilege: "(a) the nature of the actor's conduct, (b) the nature of the expectancy with which his conduct interferes, (c) the relations between the parties, (d) the interest sought to be advanced by the actor, and (e) the social interests in protecting the expectancy on the one hand and the actor's freedom of action on the other hand."

The common law cases are discussed in Coons, Non-Commercial Purpose as a Sherman Act Defense, 56 Nw. U.L. Rev. 705, 713-26 (1962).

2 Montague \& Co. v. Lowry, 193 U.S. 38, 45 (1904); Fashion Originators' Guild v. FTC, 312 U.S. 457, 465 (1941) ; Binderup v. Pathe Exch., Inc., 263 U.S. 291, 311-12 (1923); Eastern States Retail Lumber Dealers' Ass'n v. United States, 234 U.S. 600, 611-12 (1914). 
bination is restrained by their agreement not to deal with the victim;3 (3) the freedom of action of the victim is restrained in that he can no longer trade with members of the combination; 4 (4) the victim may be coerced into activity, such as price-fixing, which is itself a restraint of trade; 5 (5) the victim may be driven out of business, and trade therefore restrained because there are fewer competitors in the field; $6(6)$ the boycott may be symptomatic of dangerous power in the hands of a combination that has made itself an "extragovernmental agency."7

After a brief discussion of the extent to which modern antitrust law seems to have precluded the possibility of justification for boycotts, this comment will concentrate upon an alternative strategy-that of finding which of the possible economic sanctions lie outside the strict holdings of the antitrust cases. ${ }^{8}$

\section{The Possibility of Justification}

It would seem at first that the question of permitting justifications in antitrust boycott cases was settled in the negative long ago by the Fashion Originators' Guild case. 9 The Guild was an association of dress manufacturers concerned with stamping out the trade abuse known as "style piracy"- the copying of original dress designs by unscrupulous competitors. The Guild

3 Klor's, Inc. v. Broadway-Hale Stores, Inc., 359 U.S. 207, 213 (1959). Paramount Famous Lasky Corp. v. United States, 282 U.S. 30, 41 (1930); United States v. First Nat'l Pictures, Inc., 282 U.S. 44, 54 (1930); United States v. Associated Press, 52 F. Supp. 362, 368 (S.D.N.Y. 1943). See also Kates v. Lefkowitz, 28 Misc. 2d 210, 216 N.Y.S.2d 1014 (Sup. Ct. 1961), where the court in a dictum suggested that the state antitrust law could be applied to cases of housing segregation: "If the owners of property in a certain section agree not to rent to Negroes, in addition to the restrictive monopoly thereby established against Negroes there will exist a restraint arising from the obligation undertaken and the pressure of the group upon the free exercise of judgment on the part of individual members of the group who might, if not subjected to such influence or coercion, be later inclined to change their views." Id. at 1019.

4 Eastern States Retail Lumber Dealers' Ass'n v. United States, 234 U.S. 600, 611 (1914); Loewe v. Lawlor, 208 U.S. 274, 303 (1908); United States v. Insurance Bd., 144 F. Supp. 684, 698 (N.D. Ohio 1956).

5 Union Circulation Co. v. FTC, 241 F.2d 652, 657 (2d Cir. 1957).

6 Klor's, Inc. v. Broadway-Hale Stores, Inc., 359 U.S. 207, 213 (1959); Fashion Originators' Guild v. FTC, 114 F.2d 80, 85 (2d Cir. 1940); Fashion Originators' Guild v. FTC, 312 U.S. 457, 465 (1941); Arkansas Wholesale Grocers' Ass'n v. FTC, 18 F.2d 866, 870 (8th Cir. 1927); Hub Auto Supply, Inc. v. Automatic Radio Mfg. Co., 173 F. Supp. 396, 397 (D. Mass. 1959).

7 Fashion Originators' Guild v. FTC, 312 U.S. 457, 465 (1941); American Medical Ass'n v. United States, 130 F.2d 233, 249 (D.C. Cir. 1942); FTC v. Wallace, 75 F.2d 733, 737 (8th Cir. 1935); United States v. New Orleans Ins. Exch., 148 F. Supp. 915, 920 (E.D. La. 1957).

8 For general surveys of the antitrust law pertaining to concerted refusals to deal, see Barber, Refusals to Deal Under the Federal Antitrust Laws, 103 U. PA. L. REv. 847 (1955); Kirkpatrick, Commercial Boycotts as Per Se Violations of the Sherman Act, 10 GEO. WASH. L. REV. 302 (1942).

9 Fashion Originators' Guild v. FTC, 312 U.S. 457 (1941). 
established a bureau for the registration of original dress designs, and members agreed to boycott any retailer who persisted in selling unregistered, "pirated" dresses. The FTC issued a cease and desist order against the plan and refused to receive evidence about the purpose it was designed to serve. On appeal, the order was approved by Judge Learned Hand:

Certainly it is not true that the lawfulness of every combination depends upon whether it 'reasonably' corrects trade 'abuses'; there are some combinations that nothing will excuse. . . . Price fixing is not . . the only means unlawful per se; the interest of the consumer is not all that determines the 'reasonableness' of a contract 'in restraint of trade.' It is also unlawful to exclude from the market any of those who supply it-assuming that there is no independent reason by virtue of their conduct to justify their exclusion -and it is no excuse for doing so that their exclusion will result in benefits to consumers, or to the producers who remain. ${ }^{10}$

Instead of being a landmark case against justification for boycotts, Fashion Originators' was followed by two decades of confusion, during which it seemed quite probable that "good" boycotts would be excused. Acting in the "rule of reason" tradition, courts refused to punish such boycotts. The opinions frequently employed the doctrine that a private plaintiff must prove the existence of "public injury,"11 while also expressing approval of the purposes served by the activity.12 Fashion Originators' was gradually distinguished away.13

10 Fashion Originators' Guild v. FTC, 114 F.2d 80, 84-85 (2d Cir. 1940), aff'd 312 U.S. 457 (1941). Elaborating on the idea that there may be an "independent reason by virtue of their conduct" to justify the exclusion of a trader, Judge Hand stated: "In the case at bar, for example, it would be a lawful form of self-help for members of the Guild to refuse in combination to deal with retailers who knowingly bought dresses of those who had stolen 'unpublished' designs; or who had got access to them by any other crime, or by a breach of promise not to use them. ..." Id. at 84. This possible exception was not mentioned by the Supreme Court in its opinion.

The opinion in Ruddy Brook Clothes, Inc. v. British \& Foreign Marine Ins. Co., 195 F.2d 86 (7th Cir. 1952), suggests that a court might use the existence of this possible exception to refute the general proposition that boycotts are illegal per se. The court said that if boycotts were illegal per se "it must be because all agreements restrictive of trade are illegal and would inevitably lead to the result that concerted refusal to sell fire insurance to a known fire-bug or concerted refusal to sell fire arms to a known or suspected bank robber would constitute a violation of the Sherman Act." Id. at 89. See also United States v. American Livestock Comm'n Co., 279 U.S. 435 (1929), where the court held that stockyards traders did not have to deal with a sellers co-operative which was acting ultra vires because the traders were merely refusing to co-operate in an illegal act. While holding that the effort to drive the co-operative out of business altogether was illegal, the court recognized the relevance of purpose: "It is said that motive does not matter, but motive may be very material when it is sought to justify what until justified is a wrong." Id. at 437-38. On similar facts, but where the victim of a boycott was accused of misconduct and unfair practices, rather than acting ultra vires, a court pointed out that although a concerted refusal to enter into illegal relations might be excusable, illegal conduct on the part of the victim could not, in itself, excuse a boycott. Farmers' Livestock Comm'n Co. v. United States, 54 F.2d 375 (E.D. III. 1931).

11 The "public injury" doctrine grew out of the Court's conception of the purpose of the Sherman Act as set out in Apex Hosiery Co. v. Leader, 310 U.S. 469, 500-01 (1940). The 
Opposed to this trend were other cases applying the per se rule-the historic exception to the antitrust law's "rule of reason"14-which categorized refusals to deal in such a way that assertions about lack of "public injury," or possible justifications for "good purpose" or "noncommercial purpose"15

case did not involve a boycott, but the refusal of members of a union to permit shipment of certain carloads of hosiery being stored at a factory they were striking. It was limited to its facts as a labor case in Klor's, Inc. v. Broadway-Hale Stores, Inc., 359 U.S. 207, 213 n.7 (1959). The "public injury" requirement has not been applied to cases involving per se violations. See note 17 infra.

12 Ruddy Brook Clothes, Inc. v. British \& Foreign Marine Ins. Co., 195 F. 2d 86 (7th Cir. 1952) (refusal to sell fire insurance following report by the National Board of Fire Underwriters); United States v. Insurance Bd., 144 F. Supp. 684 (N.D. Ohio 1956) (refusal of agents to sell mutual insurance); United States v. Twentieth Century-Fox Film Corp., 137 F. Supp. 78 (S.D. Cal. 1956) (refusal by movie distributors to allow telecast of 16-mm. "feature films"); Interborough News Co. v. Curtis Publishing Co., 127 F. Supp. 286 (S.D.N.Y. 1954) (switching magazine patronage from large wholesaler to a number of small ones); Hughes Tool Co. v. Motion Picture Ass'n, 66 F. Supp. 1006 (S.D.N.Y. 1946) (refusal to show movies not approved by Motion Picture Ass'n) (dictum).

13 In citing Fashion Originators', many courts seem to have overlooked its approval of the FTC's action in refusing even to hear evidence about the purpose of the program. Instead, the case was regarded as just another instance where a combination's purposes were clearly harmful. United States v. Insurance Bd., 144 F. Supp. 684, 697-98 (N.D. Ohio 1956): "An examination of the cases cited in support of the dicta [that boycotts are illegal per se] reveals that in all of them the vice of illegality was inherent in the unlawful objectives of the combination and in the means employed to accomplish their purposes. . . . Among the many factors that condemned the boycott in Fashion Originators Guild . . . was the aim of the combination to destroy 'one type of manufacture and sale which competed with Guild members.' "

Interborough News Co. v. Curtis Publishing Co., 127 F. Supp. 286, 300 (S.D.N.Y. 1954): "On analysis, it seems that the boycott itself was not condemned as an unreasonable restraint of trade in each of those cases, but rather the Court condemned either what was sought to be accomplished by the concerted refusals to deal or what was the necessary result thereof. ... In Fashion Originators' Guild . . . the boycott was held to tend toward the creation of a monopoly in the participants. ...."

14 Standard Oil Co. v. United States, 221 U.S. 1, 65 (1911).

15 If courts were inclined to take the purposes of a concerted refusal to deal into consideration,one might suggest that they distinguish cases where the purpose is "commercial" from cases where the purpose is "non-commercial." Such refusals to deal were held illegal in Council of Defense v. International Magazine Co., 267 Fed. 390 (8th Cir. 1920) (boycott of unpatriotic publications); Kates v. Lefkowitz, 28 Misc. 2d 210, 216 N.Y.S.2d 1014 (Sup. Ct. 1961) (state antitrust law applied to racial housing discrimination). Such refusals to deal were found to be legal in Young v. Motion Picture Ass'n, 1961 Trade Cas. 70,139 (D.D.C. 1961) (boycott of movie writers suspected of communist affiliation); Molinas v. National Basketball Ass'n, 190 F. Supp. 241 (S.D.N.Y. 1961) (suspension of basketball player violating anti-betting rule). See Note, Industry Self-Regulation in the Field of Public Morality, in Schwartz, Free ENTERPRISE AND Economic ORganization 367-69 (2d ed. 1959). The per se rule, however, would seem to preclude a showing of non-commercial purpose as a justification just as surely as it precludes a showing of good purposes. Furthermore, it would be hard to say that any boycott is purely non-commercial in character. No matter what the ultimate aim of the combination, a boycott generally involves the infliction of some commercial harm upon the person the combination is trying to coerce into changing his ways.

Compare Swan v. First Church of Christ, Scientist, 225 F.2d 745 (9th Cir. 1955), where the court said there was no cause of action under the antitrust laws against a church refusing 
would be irrelevant. ${ }^{16}$ With the Klor's case in 195917 and the Radiant Burners ${ }^{18}$ case in 1961, the triumph of the per se rule seemed complete. In Radiant Burners, the defendant American Gas Association attempted to justify a program undertaken to halt the sale and use of unsafe gas burners and appliances by the issuance of seals of approval - the denial of a seal being allegedly enforced by various refusals to deal including the refusal of utilities to furnish gas for use in the offending appliance. The Supreme Court was unimpressed

to sell plaintiff's book in branch churches and reading rooms, because of "the absolute right of any religious order to select its own ministers, advocates, authors and sacred writings." Id. at 751.

But see Coons, Non-Commercial Purpose as a Sherman Act Defense, 56 Nw. U.L. Rev. 705,748 (1962), where it is asserted that "the proposition that non-commercial purpose, in some cases, will justify otherwise forbidden restraints seems fairly predictable" from an "examination of the labor cases," and that "this conclusion is unaffected by any authority to the contrary in the commercial cases, all of which ignore purpose altogether. It is assisted by the authority of the common-law cases, which stress the relevance of beneficent purposes, both economic and non-economic." In discussing the rule that concerted refusals to deal are per se violations of the Sherman Act, Coons states: "It is my position that that view and these cases are beside the point, for they assume a factual situation involving businessmen seeking to preserve and advance their commercial enterprise. The approach suggested here, for the cases of our special interest, stands or falls upon the non-economic character of the purpose involved. If this distinction is rejected, antitrust liability follows in the most mechanical, and frequently absurd, fashion. I cannot believe that the Supreme Court would apply the per se rule to the Montgomery bus boycott." Id. at 752 .

16 Radovich v. National Football League, 352 U.S. 445 (1957); New Home Appliance Center v. Thompson, 250 F.2d 881 (10th Cir. 1957); Hub Auto Supply Inc. v. Automatic Radio Mfg. Co., 173 F. Supp. 396 (D. Mass. 1959); Evening News Publishing Co. v. Allied Newspaper Carriers, 160 F. Supp. 568 (D.N.J. 1958); United States v. New Orleans Ins. Exch., 148 F. Supp. 915 (E.D. La. 1957); United States v. Minneapolis Elec. Contractors Ass'n, 99 F. Supp. 75 (D. Minn. 1951). See dicta in Times-Picayune Publishing Co. v. United States, 345 U.S. 594, 624-25 (1953); United States v. Columbia Steel Co., 334 U.S. 495, 522-23 (1948).

17 Klor's, Inc. v. Broadway-Hale Stores, Inc., 359 U.S. 207 (1959). The Klor's case held the "public injury" doctrine not applicable to refusal to deal cases. There is some doubt whether the Court in so doing eliminated the public injury doctrine altogether, or merely isolated refusals to deal from the doctrine by putting them in the per se category. For the latter view, see Handler, Recent Developments in Antitrust Law: 1958-59, 59 Colum. L. REv. 843, 866 (1959); Oppenheim, Selected Antitrust Developments in the Courts and Federal Trade Commission during the Past Year, 15 A.B.A. ANTITRUST REP. 37, 56 (1959). The alternative position is adopted in Wragg, Private Suits under the Sherman Act: The New Injury-to-Competitors Test, 7 WAYNE L. REV. 535 (1961). Wragg asserts that the Court already has eliminated, or is about to eliminate, the public injury standard-or, as he terms it, the injury-to-competition standard-as a requirement in all private antitrust suits, replacing it with an injury-to-competitors standard in order to protect small traders. He points out that "the innovation would amount to a judicial changing of the purpose of the Sherman Act from promotion of competition in open markets to a tort purpose of individual compensation. ..." Id, at 547. Much the same interpretation seems to have been adopted in K.S. Corp. v. Chemstrand Corp, 198 F. Supp. 310 (S.D.N.Y. 1961).

For further discussion of the public injury problem, see Note, 23 U. PITT. L. REV. 737 (1962); Note, 1961 Duke L.J. 606 (1961); Note, 1961 Duke L.J. 302 (1961); Note, 12 WeST. RES. L. REV. 759 (1961).

18 Radiant Burners, Inc. v. Peoples Gas Light \& Coke Co., 364 U.S. 656 (1961). 
by the Association's "good purposes" and found the refusal to deal a violation of the Sherman Act because it was by its "nature or character . . . unduly restrictive."'19

\section{The Different Types of Economic Sanctions}

The rejection of justification arguments by the Klor's and Radiant Burners cases suggests the time is appropriate for trying an approach that rescues at least some kinds of private economic sanctions from the reach of the broadlyworded per se rule by distinguishing the antitrust cases on their facts.

All economic sanctions may be said to involve a refusal to deal, and thus are similar in that they isolate a "victim" in some way from economic relationships which are vital to him. Although social groups in general are said to be able to enforce norms of behavior by use of the threat of isolation, 20 the possibility of escaping such coercion by reconciling oneself to the isolation would seem to render the purely social situation distinguishable from the economic. The economic unit cannot accept isolation; a business lacking suppliers or customers or access to necessary facilities will cease to exist. Consequently, the law must undertake to regulate the use of refusals to deal, although methods of economic isolation may be just as subtle, elusive, and difficult of definition as are methods of social isolation.

In classifying different types of economic sanction or refusals to deal, it will be useful first to examine the facts of both the tort and antitrust cases in the area, in addition to other descriptive materials. Refusals to deal can be conveniently classified as "direct" refusals to deal, and those brought about by the use of secondary pressures. Instances involving secondary pressures can in turn be divided into those where the secondary pressure is another refusal to deal, those where the pressure relies upon some special relationship, and those where some form of persuasion is used.

(1) Direct refusal to deal. - The group in the most favorable position for coercing the behavior of a trader is one that, by ceasing its own dealings with the trader, will have cut him off from a vital economic relation. Thus, groups of buyers, by threatening a refusal to buy, have coerced sellers into conforming to a strict chain of distribution, 21 altering prices and terms ${ }^{22}$ and joining an association. 23 Groups of sellers, on the other hand, have coerced buyers into paying debts promptly, ${ }^{24}$ reselling at a prescribed price, 25 buying

19 Id. at 659.

20 Homans, The Human Group 281 (1950).

21 Eastern States Retail Lumber Dealers' Ass'n v. United States, 234 U.S. 600 (1914).

22 Paramount Pictures, Inc. v. United Motion Picture Theatre Owners, 93 F.2d 714 (3d Cir. 1937).

23 Purington v. Hinchliff, 219 IIl. 159, 76 N.E. 47 (1905). A refusal to buy was used to influence the policies of a newspaper in Greenspun v. McCarran, 105 F. Supp. 662 (D. Nev. 1952); Baldwin v. Escanaba Liquor Dealers' Ass'n, 165 Mich. 98, 130 N.W. 214 (1911).

24 United States v. First Nat'l Pictures, Inc., 282 U.S. 44 (1930); United States v. Fur Dressers' \& Fur Dyers' Ass'n, 5 F.2d 869 (S.D.N.Y. 1925).

25 Kiefer-Stewart Co. v. Joseph E. Seagram \& Sons, Inc., 340 U.S. 211 (1951). 
unwanted products, 26 and buying only from members of an association. 27 Where members of a trade are accustomed both to buy and sell from each other, great coercive power can be exercised by an association of traders which threatens to cut off the person being coerced.28 Groups and individuals in control of vital facilities such as theaters, newsstands, and auction warehouses can exercise great power through a direct refusal to deal.29 Disruption

${ }^{26}$ Ellis v. Inman, Poulsen \& Co., 131 Fed. 182 (9th Cir. 1904); PEARCE, TRADE AssociaTION SURVEY 92 (TNEC Monograph No. 18, 1941).

${ }^{27}$ Speegle v. Board of Fire Underwriters, 29 Cal. 2d 34, 172 P.2d 867 (1946). Forcing buyer to cease selling second-hand magazines: Butterick Publishing Co. v. FTC, 85 F.2d 522 (2d Cir. 1936). Pressures by motion picture distributors upon exhibitors have been frequently litigated, as where the exhibitor is forced to deal with all members of an association, Binderup v. Pathe Exch., Inc., 263 U.S. 291 (1923); use a standard form contract, Paramount Famous Lasky Corp. v. United States, 282 U.S. 30 (1930); or refrain from televising movies, United States v. Twentieth Century-Fox Film Corp., 137 F. Supp. 78 (S.D. Cal. 1956). See generally, Pearce, Trade Association Survey 101 (TNEC Monograph No. 18, 1941).

${ }^{28}$ This has been the case among traders on livestock and produce exchanges. United States v. American Livestock Comm'n Co., 279 U.S. 435 (1929); Anderson v. United States, 171 U.S. 604 (1898); Hopkins v. United States, 171 U.S. 578 (1898); Farmers' Livestock Comm'n Co. v. United States, 54 F.2d 375 (E.D. Ill. 1931); Carnes v. St. Paul Union Stockyards Co., 164 Minn. 457, 205 N.W. 630 (1925); Ertz v. Produce Exch. Co., 79 Minn. 140, 81 N.W. 737 (1900); Gladish v. Bridgeford, 113 Mo. App. 726, 89 S.W. 77 (1905). Similar pressures can be exerted by a professional association when members of the profession must of necessity work closely with each other. United States v. Oregon State Medical Soc'y, 343 U.S. 326 (1952); American Medical Ass'n v. United States, 317 U.S. 519 (1943); Spears Free Clinic \& Hospital for Poor Children v. Cleere, 197 F.2d 125 (10th Cir. 1952); Harris v. Thomas, 217 S.W. 1068 (Tex. App. 1920). See also Associated Press. v. United States, 326 U.S. 1 (1945).

${ }^{29}$ Thus, the force behind the efforts of the Motion Picture Association to censor the content of movies seems to be a threatened denial of theatre outlets to movies which do not obtain the Association's seal of approval. Note, Entertainment: Public Pressures and Law, 71 HaRv. L. Rev. 326, 354-55 (1957); Hughes Tool Co. v. Motion Picture Ass'n, 66 F. Supp. 1006 (S.D.N.Y. 1946). In an English case, theatre owners banded together to coerce the manager of a traveling show into raising low wages which among other things had driven his chorus girls to prostitution. Brimelow v. Casson, [1924] $1 \mathrm{Ch} .302$.

Similarly, refusals by newsstands to handle blacklisted magazines and books have been attempted as a method of enforcing censorship programs. Council of Defense v. Int'l Magazine Co., 267 Fed. 390 (8th Cir. 1920). A central feature of the campaign of the National Organization for Decent Literature against obscene magazines and paper-back books was the pressuring of newsstands into refusing to handle blacklisted publications. National Organization for Decent Literature, The Drive for Decency in Print (1939); Report on Book Burning, 10 ReCoRD of N.Y.C.B.A. 143 (1955); Statement on Censorship Activity by Private Organizations and the National Organization for Decent Literature, American Civil Liberties Union Weekly Bulletin No. 1902 (1957).

Similar coercion is applied by denial of broadcast time, McIntire v. Wm. Penn Broadcasting Co., 151 F.2d 597 (3d Cir. 1945); Watch Tower Bible \& Tract Soc'y v. Dougherty, $337 \mathrm{~Pa} .286,11$ A.2d 147 (1940); advertising space, United States v. General Outdoor Advertising Co., 1955 Trad Cas. 68,169 (N.D. Ill. 1955); United States v. Lyman Gun Sight Corp., 1957 Trade Cas. 68,851 (D.D.C. 1957); space and selling time in an auction warehouse, Rogers v. Douglas Tobacco Bd. of Trade, Inc., 266 F.2d 636 (5th Cir. 1959); American Fed'n of Tobacco Growers, Inc. v. Neal, 183 F.2d 869 (4th Cir. 1950); Gamco, Inc. v. Providence Fruit \& Produce Bldg., 194 F.2d 484 (1st Cir. 1952); access to harbor and railroad terminal facilities, United States v. Terminal R.R. Ass'n, 224 U.S. 383 (1912); United States v. Great Lakes Towing Co., 208 Fed. 733 (N.D. Ohio 1913); and private telephone connections to a brokerage house, Silver v. New York Stock Exch., 196 F. Supp. 209 
of the employment relation has been used as an economic sanction not only by unions through concerted refusals to work, 30 but by employers through concerted refusals to employ, 31 as where a blacklist of suspected Communists is circulated in the movie industry, 32 or members of a professional basketball league refuse to hire a player expelled for violating the rules. 33

(2) Secondary refusal to deal.-The reach of a group's economic power is extended when it refuses to deal with an intermediary in order to coerce the intermediary in turn to refuse to deal with the victim. The classic method by which an association of merchants is able to put pressure on a competitor, or drive him out of business, is a refusal to buy from suppliers unless the suppliers refuse to sell to the competitor. ${ }^{34}$ Similar effect is produced by a refusal to sell to customers unless the customers refuse to buy from the competitor. 35 Secondary refusals to deal are used generally by groups which wish to regulate the behavior of a trader, but which are not in an economic relationship allowing coercion by means of a direct refusal to deal.36

(3) Other secondary pressures.-A refusal to deal by an intermediary can often be provoked by a means which itself cannot strictly be called a refusal to deal. This method may depend upon a special relationship to the inter-

(S.D.N.Y. 1961), rev'd 302 F.2d 714 (2d Cir. 1962), cert. granted, 83 Sup. Ct. 26 (1962). Several cases, in addition, have dealt with the refusal of associations of insurance agents to sell for mutual insurance companies, United States v. Insurance Bd., 144 F. Supp. 684 (N.D. Ohio 1956), 188 F. Supp. 949 (N.D. Ohio 1960); United States v. New Orleans Ins. Exch., 148 F. Supp. 915 (E.D. La. 1957).

30 The use of economic sanctions by labor unions, governed by statute, and largely exempt from the antitrust laws, is beyond the scope of this comment. See Allen Bradley Co. v. International Bhd. of Elec. Workers, 325 U.S. 797 (1945); Hunt v. Crumboch, 325 U.S. 821 (1945); United States v. Hutcheson, 312 U.S. 219 (1941); ATT'y GeN. Nat'l Comm. ANTITRUST REP. 293-306 (1955).

31 Radovich v. National Football League, 352 U.S. 445 (1957); Union Circulation Co. v. FTC, 241 F.2d 652 (2d Cir. 1957).

32 Young v. Motion Picture Ass'n, 28 F.R.D. 2 (D.D.C. 1961); Wilson v. Loew's Inc., 142 Cal. App. 2d 183, 298 P.2d 152 (Dist. Ct. App. 1956).

33 Molinas v. National Basketball Ass'n, 190 F. Supp. 241 (S.D.N.Y. 1961).

34 Klor's, Inc. v. Broadway-Hale Stores, Inc., 359 U.S. 207 (1959).

35 Fashion Originators' Guild v. FTC, 312 U.S. 457 (1941).

36 In Webb v. Drake, 52 La. Ann. 290, 26 So. 791 (1899), defendant merchants were angry at plaintiff hotel owner because plaintiff while acting as assessor of the parish had indicted some of them for failure to make tax returns. In order to drive the plaintiff out of business, the merchants refused to deal with any traveling salesmen who stayed in plaintiff's hotel.

In Davis v. Barnett, 26 U.C.Q.B. 109 (Can. 1866), defendant and plaintiff were both in the business of renting raincoats to tourists for use in traveling under Niagrara Falls. Defendant attempted to drive plaintiff out of business by falsely representing to tourists that they could not use a stairway leading to the falls if they rented raincoats from the plaintiff.

In Watch Tower Bible \& Tract Soc'y v. Dougherty, 337 Pa. 286, 11 A.2d 147 (1940), a religious group was able to get a rival group's broadcasting contract cancelled by threatening a boycott of a department store which owned the radio station. 
mediary, as when a school orders its pupils not to patronize a merchant, 37 or when similar orders are given by an employer to his employees, 38 a union to its members, 39 or a church to its faithful. 40 Some form of more or less effective persuasion may also be used. Picketing, for example, has been a favorite form of action by private groups. 41 The circulation of adverse information about a product can have considerable economic impact, depending upon the nature of its source. Although the power wielded in this way by competitors and crackpots may be negligible, 42 considerably more impact may be expected when adverse information is distributed through books, newspapers, and publications of mercantile agencies; 43 and a business can be seriously endangered when an organization with great prestige enters the field, such as the

${ }^{37}$ Speyer v. School Dist., 82 Colo. 534, 261 P. 859 (1927); Guethler v. Altman, 26 Ind. App. 587, 60 N.E. 355 (1901); Gott v. Berea College, 156 Ky. 376, 161 S.W. 204 (1913); Jones v. Cody, 132 Mich. 13, 92 N.W. 495 (1902); Hutton v. Watters, 132 Tenn. 527, 179 S.W. 134 (1915).

38 Deon v. Kirby Lumber Co., 162 La. 671, 111 So. 55 (1927); Graham v. St. Charles St. Ry., 47 La. Ann. 214, 16 So. 806 (1895); Wesley v. Native Lumber Co., 97 Miss. 814, 53 So. 346 (1910); Payne v. Western \& Atl. R.R., 81 Tenn. (13 Lea) 507 (1884).

39 Petty v. Dayton Musicians' Ass'n, 153 N.E.2d 223 (Ohio 1958). Similar cases involving directions by an association to its members are American Medical Ass'n v. United States, 317 U.S. 519 (1943); Silver v. New York Stock Exch., 196 F. Supp. 209 (S.D.N.Y. 1961), rev'd, 302 F.2d 714 (2d Cir. 1962), cert. granted, 83 Sup. Ct. 26 (1962); Terry v. Dairymen's League Co-op. Ass'n, 157 N.Y.S.2d 71, 2 App. Div. 2d 494 (1956).

40 Kuryer Publishing Co. v. Messmer, 162 Wis. 565, 156 N.W. 948 (1916); Heinrichs v. Wiens, 8 Sask. L. 153, 23 D.L.R. 664 (1915). For activities of the Catholic Legion of Decency in inducing boycotts of unapproved movies, see Note, Entertainment: Public Pressures and the Law, 71 HARV. L. Rev. 326, 360-62 (1957).

41 Picketing has been a popular form of action taken against motion pictures by offended groups, as where Charlie Chaplin movies are picketed by the American Legion, Note, supra note 40 , at 363; "Birth of a Nation" by the NAACP, ibid.; "Island in the Sun" by the Ku Klux Klan, N.Y. Times, Aug. 17, 1957, p. 7, col. 1; "The Iron Curtain" by the New York Committee Against War Propaganda, id., May 14, 1948, p. 28, col. 6; and "The Desert Fox" by the Manhattan Jewish Conference, id., Dec. 10, 1951, p. 34, col. 2.

This form of pressure has also been used by Negro groups attempting to coerce merchants into integrated hiring practices, New Negro Alliance v. Sanitary Grocery Co., 303 U.S. 552 (1938); Green v. Samuelson, 168 Md. 421, 178 A. 109 (1935); A. S. Beck Shoe Corp. v. Johnson, 153 Misc. 363, 274 N.Y.S. 946 (Sup.Ct. 1934); by consumers seeking to remedy high prices, Julie Baking Co. v. Graymond, 152 Misc. 846, 274 N.Y.Supp. 250 (Sup. Ct. 1934); and by merchants seeking to coerce a price-cutting competitor, Saveall v. Demers, 322 Mass. 70, 76 N.E.2d 12 (1947); Bernstein v. Retail Cleaners' \& Dyers' Ass'n, 31 Ohio N.P. (n.s.) 433 (1934).

42 Royer v. Stoody Co., 192 F. Supp. 949 (W.D. Okla. 1961); Scientific Mfg. Co. v. FTC. 124 F.2d 640 (3d Cir. 1941); American Malting Co. v. Keitel, 217 Fed. 672 (S.D.N.Y. 1914); Menard v. Houle, 298 Mass. 546, 11 N.E.2d 436 (1937) (dissatisfied automobile purchaser fastening lemons and derogatory signs to the car); McMorries v. Hudson Sales Corp., 233 S.W.2d 938 (Tex. App. 1950).

43 Douglas v. Daisley, 114 Fed. 628 (1st Cir. 1902); Krebiozen Research Foundation v. Beacon Press, Inc., 334 Mass. 86, 134 N.E.2d 1 (1956); Lawrence Trust Co. v. Sun-American Publishing Co., 245 Mass. 262, 139 N.E. 655 (1923); Pollasky v. Minchener, 81 Mich. 280, 46 N.W. 5 (1890); Gibralter Sav. \& Bldg. Ass'n v. Isbell, 101 S.W.2d 1029 (Tex. App. 1937). 
government, ${ }^{44}$ a professional association, 45 a better business bureau, 46 or a consumers association. 47 Omission of a business from a listing or rating, 48 or refusal to grant it a seal of approval, can be just as damaging as the circulation of adverse information, and considerable influence has thus been exerted by various product-testing programs. 49

${ }^{44}$ Hoxsey Cancer Clinic v. Folsom, 155 F. Supp. 376 (D.D.C. 1957); Council of Defense v. International Magazine Co., 267 Fed. 390 (8th Cir. 1920).

45 Appalachian Power Co. v. American Institute of Certified Pub. Accountants, 268 F.2d 844 (2d Cir. 1959); Professional \& Business Men's Life Ins. Co. v. Bankers Life Co., 163 F. Supp. 274 (D. Mont. 1958).

46 Best Window Co. v. Better Business Bureau, 146 N.Y.S.2d 382, 2 Misc. $2 d 55$ (Sup. Ct. 1955).

47 The sales of a loudspeaker manufacturer dropped from $\$ 100,000$ to $\$ 40,000$ in one year after receiving a "not acceptable" rating from Consumers Union, while a competing firm doubled its sales after receiving a rating of "acceptable-very good." Wall Street Journal, March 15, 1962, p. 12, col. 3.

48 Davis v. New England Ry. Publishing Co., 203 Mass. 470, 89 N.E. 565 (1909) (omission from directory of express companies); Advance Music Corp. v. American Tobacco Co., 296 N.Y. 79, 70 N.E.2d 401 (1946) (omission from list of "most popular" songs); Dale System, Inc. v. General Teleradio, Inc., 105 F. Supp. 745 (S.D.N.Y. 1952) (competitor said to be "the only company of its kind").

$49 \mathrm{~A}$ brand of toothpaste endorsed by the American Dental Association increased its share of the market from $12 \%$ to $26 \%$ in 14 months while at the same time the market share of its biggest competitor declined from $33 \%$ to $27 \%$. Wall Street Journal, Oct. 16, 1961, p. 6, col. 2. A manufacturer of a therapeutic lamp claimed that endorsement of a competitor's product by the American Medical Association was part of a conspiracy to drive him out of business. Boerstler v. American Medical Ass'n, 16 F.R.D. 437 (N.D. Ill. 1954). Similar claims were made by lumber producers who were denied the use of an association's grademark. See cases cited note 103 infra.

There are important differences between product testing programs undertaken by producer trade associations, by independent consumer testing agencies, and by government agencies. See Gragg \& Borden, Merchandise Testing as a Guide to Consumer Buying, (Harv. Bus. School Research Study No. 22, 1938). The trade association program, designed to win public confidence and cut waste by standardizing the product, generally relies upon voluntary compliance by individual members of the industry in order to succeed. LAMB \& Kittelle, Trade Association LaW \& Practice 92 (1956); Mitchell, How to Use Your Trade Association 91, 97 (1951); The Magazine of Standards, pt. 2, p. 7 (March 1961): "The existence of an American Standard does not in any respect preclude any party who has approved of the standard from manufacturing, selling, or using products, processes, or procedures not conforming to the standard." Programs to help the consumer judge the quality of products, generally undertaken by independent agencies such as Consumers Research Institute, depend for their effectiveness on acceptance of the program by the public. Auerbach, Quality Standards, Informative Labeling, and Grade Labeling as Guides to Consumer Buying, 14 LAW \& CONTEMP. Prob. 362-63 (1949); KaIDANOvSKY \& EDWARds, Consumer Standardos 312-13 (TNEC Monograph No. 24, 1941). The type of program associated with government agencies is that undertaken to assure compliance with certain minimum standards necessary to protect the public health and safety. GRAGG \& BORDEN, op. cit. supra, at 68 . This is the only one of the three types of programs which seems to require some kind of coercion to make it effective. Nevertheless, trade associations have occasionally resorted to coercion to put teeth into their evaluation programs, as where the Motion Picture Association caused member exhibitors to refuse to show unapproved movies, Hughes Tool Co. v. Motion Picture Ass'n, 66 F. Supp. 1006 (S.D.N.Y. 1946), or 


\section{Scope of the Antitrust Rule: Secondary Refusals to Deal}

Klor's, and many of the other antitrust cases, involved what we have called "secondary refusals to deal," coupled with a purpose to coerce or eliminate a competitor. ${ }^{50}$ The fact that the cases have uniformly condemned such schemes, often without any language about "reasonableness," has been taken to mean that courts have long regarded the activity as illegal per se.51 Apart from the fact that competitors are usually involved, a blanket rule of illegality for secondary refusals to deal is justified by the fact that such activity involves a large extension of a group's normal economic power and coercion of a neutral intermediary. 52 Even where the combination is said to be pursuing some "good purpose"- to be achieved by coercing the conduct of the ultimate victim-such purpose is rarely a consolation to the intermediary who is forced to sacrifice his freedom of trade in the process.

\section{Scope of the Antitrust Rule: Direct Refusals to Deal}

There are several ways in which direct refusals to deal may be contrasted with secondary refusals to deal. The problem of injury to an intermediary is not involved in a direct refusal to deal, nor is the problem of undue extension of normal economic power through the use of the intermediary. In addition, direct refusals to deal are not always aimed exclusively at the elimination of competitors, but involve a variety of other purposes, most of which have also been found illegal, such as preserving a rigid chain of distribution favorable

where the American Gas Association causes members to refuse to furnish gas for use in unapproved products, Radiant Burners, Inc. v. Peoples Gas Light \& Coke Co., 364 U.S. 656 (1961). Such activity opens the association to the charge that it has thus made itself a quasigovernmental agency.

50 An exception would be Radiant Burners v. Peoples Gas Light \& Coke Co. 364 U.S. 656 (1961), where the particular activity condemned was a threatened refusal to deal by utilities aimed at causing a consumers' refusal to deal with the plaintiff manufacturer. The defendant American Gas Association, however, included competitors of the plaintiff.

51 Kirkpatrick, Commercial Boycotts as Per Se Violations of the Sherman Act, 10 Gro. WASH. L. REV. 302 (1942).

52 Policy distinctions between primary and secondary economic pressures have been clearly drawn along these lines in labor law: "Sec. 8 (b)(4)(A) was not intended by Congress, as the legislative history makes abundantly clear, to curb primary picketing. It was intended only to outlaw certain secondary boycotts, whereby unions sought to enlarge the economic battleground beyond the premises of the primary Employer." Local 618, Automotive Union v. NLRB, 249 F.2d 332 (8th Cir. 1957).

"The provisions of section 9 (b)(4)(A), (B) and (C) of the National Labor Relations Act which prohibit secondary boycotts are designed to protect innocent third parties from being injured in labor disputes with which they are not concerned and for the existence of which they bear no responsibility. As the President pointed out, the true secondary boycott which inficts economic injury on employers who are genuine neutrals in the dispute between some other employer and his employees, is indefensible." S. REP. No. 1211, 83rd Cong., 2d Sess. 10-11 (1954). 
to the combination, 53 fixing resale prices, 54 forcing prompt payment of debts, 55 forcing the buyer to buy unwanted products or deal with every member of an association, 56 forcing the use of a form contract, 57 preventing the sale of second-hand magazines, 58 and attempting to eliminate a crusading newspaper.59 Some, however, of the diverse purposes of direct refusals to deal have met with approval by the courts. 60

Perhaps the most significant contrast between secondary and direct refusal to deal cases, is the different use that they make of the requirement that a conspiracy be shown in order to prove a violation of section 1 of the Sherman Act. This problem seems never to arise in the secondary refusal to deal cases, even though a single large business rather than a combination is often involved, because the plaintiff in these cases is always able to name as a coconspirator the neutral group by which the secondary refusal to deal is carried out.61 Proof of a conspiracy, however, becomes difficult in the direct refusal to deal cases. By finding that no conspiracy exists, some courts have been able to avoid applying the per se rule, when such application would seemingly produce an unjust result.62

A "monopolization" rule seems to have been applied in many cases involving direct refusals to deal, regardless of whether a single unit or a combination was responsible for the practice. In other words, courts in these cases, far from applying the per se rule, have excused direct refusals to deal unless carried out by a group with a large degree of market dominance. A dominant group has been allowed to continue refusing to deal only when it meets some standard of fair dealing, such as must be met by a public utility. There has been confusion as to whether the monopolization standard of section 2 or the per se standard of section 1 is to be applied in a given case-a confusion

53 Eastern States Retail Lumber Dealers Ass'n v. United States, 234 U.S. 600 (1914); Wholesale Dry Goods Institute v. FTC, 139 F.2d 230 (2d Cir. 1943); United States v. Hollis, 246 Fed. 611 (D. Minn. 1917).

54 Standard Sanitary Mfg. Co. v. United States, 226 U.S. 20 (1912); Bobbs-Merrill Co. v. Straus, 139 Fed. 155 (S.D.N.Y. 1905).

55 United States v. First Nat'l Pictures, Inc., 282 U.S. 44 (1930). This purpose was held to excuse a refusal to deal, however, in United States v. Fur Dressers' \& Fur Dyers' Ass'n, 5 F.2d 869 (S.D.N.Y. 1925).

56 Binderup v. Pathe Exch., Inc., 263 U.S. 291 (1923); Ellis v. Inman, Poulsen \& Co., 131 Fed. 182 (9th Cir. 1904).

57 Paramount Famous Lasky Corp. v. United States, 282 U.S. 30 (1930).

58 Butterick Publishing Co. v. FTC, 85 F.2d 522 (2d Cir. 1936).

59 Greenspun v. McCarran, 105 F. Supp. 662 (D. Nev. 1952).

60 See Anderson v. United States, 171 U.S. 604 (1898) (forcing stockyards traders to join an association), and cases cited note 12 supra.

61 Klor's, Inc. v. Broadway-Hale Stores, Inc., 359 U.S. 207 (1959).

62 Lack of conspiracy was an alternative ground of decision in United States v. Twentieth Century-Fox Film Corp., 137 F. Supp. 78 (S.D. Cal. 1956), and Interborough News Co. v. Curtis Publishing Co., 127 F. Supp. 286 (S.D.N.Y. 1954). 
brought about by the fact that a combination, as well as a single monopolist, may "attempt to monopolize" in violation of section 2.

Thus, in cases involving a direct denial of vital facilities, courts, after finding market dominance to exist, have imposed a duty of fair dealing. 63 Such a duty was imposed in cases involving railroad terminal facilities, ${ }^{64}$ harbor facilities, 65 and space and selling time in a produce or tobacco warehouse. 66 The legality of the censorship of advertising by a newspaper, or especially an association of newspapers, has been said to depend on whether the test was fair and uniformly applied.67 In one case a magazine was enjoined in a consent decree from arbitrarily refusing advertisements of a cut-rate gunsight dealer, but was allowed to refuse advertisements that did not meet "reasonable standards uniformly applied."68 In another consent decree an outdoor advertising firm was enjoined from refusing to give advertising space "provided, however, that nothing herein shall prevent defendant from refusing to sell advertising space based on bona fide compliance with reasonable requirements as to financial responsibility or business ethics." 69

The leading case involving the relation between per se and monopolization rules in the area of direct refusals to deal is Associated Press $v$. United States, 70 where members of an association of newspapers agreed that they would sell news dispatches only to the association and to fellow members. Judge Learned Hand, writing for a special district court, said the rule operated as an illegal restraint when used in conjunction with membership rules that discriminated against newspapers that competed with members. ${ }^{71}$ Together, these rules of the association constituted a refusal to deal with competitors. In addition, Associated Press was found to have a dominant position in the market despite the existence of alternative news services because of the inter-

63 On the other hand, the existence of several radio stations was considered a good defense to an action against a radio station for arbitrarily cancelling the broadcasting contract of a religious organization. McIntire v. Wm. Penn Broadcasting Co., 151 F.2d 597 (3d Cir. 1945).

Where there was no refusal to deal, the court in one case upheld an association with control over the sport of harness racing, because "the essence of monopoly is exclusion." United States v. United States Trotting Ass'n, 1960 Trade Cas. 69,761 (S.D. Ohio 1960).

64 United States v. Terminal R.R. Ass'n, 224 U.S. 383 (1912).

65 United States v. Great Lakes Towing Co., 208 Fed. 733 (N.D. Ohio 1913).

${ }^{66}$ Rogers v. Douglas Tobacco Bd. of Trade, Inc., 266 F.2d 636 (5th Cir. 1959); Gamco, Inc. v. Providence Fruit \& Produce Bldg., 194 F.2d 484 (1st Cir. 1952); American Fed'n of Tobacco Growers, Inc. v. Neal, 183 F.2d 869 (4th Cir. 1950).

67 Baum, Self Regulation \& Antitrust-Suppression of Deceptive Advertising by the Publishing Media, 12 SYRACUSE L. REv. 289 (1961).

68 United States v. Lyman Gun Sight Corp., 1957 Trade Cas. 68,851 (D.D.C. 1957).

69 United States v. General Outdoor Advertising Co., 1955 Trade Cas. 68,169 (N.D. III. 1955).

70326 U.S. 1 (1945).

71 United States v. Associated Press, 52 F. Supp. 362 (S.D.N.Y. 1943). 
est of the public in receiving the news in "many colors."72 Thus, by virtue of its dominant position, and also by virtue of the concerted refusal to sell news to competitors not admitted to membership, the association was put under a duty to deal fairly like that placed on a monopolist.

Although Judge Hand clearly viewed the case as involving a concerted, rather than individual, refusal to deal, he gave no clear indication of how it would have been decided if the AP were not a dominant organization. Under a per se rule condemning concerted refusals to deal, the power of the combination would make no difference. If the duty of the AP, on the other hand, rests upon its monopoly position, a smaller organization would have been allowed to refuse to deal. The Supreme Court, in affirming the lower court, offered little help in this regard, depending both on the power of the combination and the fact that the rules were directed against competitors:

The net effect is seriously to limit the opportunity of any new paper to enter these cities. ...

....

... The Sherman Act was specifically intended to prohibit independent businesses from becoming "associated" in a common plan which is bound to reduce their competitor's opportunity to buy or sell the things in which the groups compete. ${ }^{73}$

The fact that the per se rule has not as yet been extended to apply to all direct refusals to deal is graphically shown by recent cases involving the concerted denial of employment. The law pertaining to direct refusals to employ was declared by the Supreme Court in Radovich v. National Football League. 74 There the plaintiff, who was refused employment in a professional football league because of his previous employment in a rival league, alleged that he therefore had been damaged as a result of a plot by the league to do away with its rival. The Supreme Court held that the complaint stated a cause of action without an allegation of injury to the public, seeming to imply that a per se rule was applicable. Three other recent cases involving a concerted refusal to employ, although decided after Radovich, have rejected the per se rule, however. In Union Circulation Co. $y . F T C, 75$ an agreement between circulation agencies not to hire magazine solicitors who quit working for a fellow member was held not to fall within the per se rule because "the 'no-switching' agreements are directed at the regulation of hiring practices and the supervision of employee conduct, not at the control of manufacturing or merchandising practices." 76 In two recent cases, expulsion of employees by concerted action of employers was held justified because of the reasonableness of

72 Id. at 371.

73326 U.S. at $13,15$.
74352 U.S. 445 (1957).

75241 F.2d 652 (2d Cir. 1957).

$76 \mathrm{Id}$. at 657 . The court went on, however, to hold the agreement an unreasonable restraint of trade because it tended to "discourage labor mobility" to the disadvantage of newer firms. Id. at 658 . 
the rules by which the expulsion was made. In Molinas v. National Basketball Ass' $n^{77}$ a player was indefinitely suspended from the National Basketball League for violating a rule against betting on his own team and was thus unable to play professional basketball. The court said this was not an illegal restraint because:

Surely, every disciplinary rule which a league may invoke, although by its nature it may involve some sort of a restraint, does not run afoul of the antitrust laws. And, a disciplinary rule invoked against gambling seems about as reasonable a rule as could be imagined. 78

In Young v. Motion Picture Ass' $n, 79$ plaintiffs were excluded from employment in the motion picture industry by virtue of the circulation of a blacklist of suspected Communists. The court decided only a procedural motion, but asserted in a dictum:

[A] fuller presentation of the facts in this case may indicate their actions do not constitute a conspiracy to restrain trade in violation of the antitrust laws, but their agreement was reasonable in view of the fact that the confidence of the public in the motion picture industry had been placed in question as a result of the Congressional investigations of the industry $\ldots . .80$

\section{SCOPE OF THE ANTITRUST RULE: OTHER SECONDARY PRESSURES}

As stated in Part II above, a category of cases distinct from either direct or secondary refusals to deal includes those in which a refusal to deal by an intermediary is provoked by means which themselves cannnot strictly be called refusals to deal. An antitrust case of this type is American Medical Ass'n $v$. United States, 81 upholding a criminal antitrust conviction for activity aimed at eliminating Group Health Association, a prepaid medical care and hospitalization plan. The AMA was accused of using the threat of expulsion in order to coerce member physicians into refusing to accept employment with Group Health and refusing to work with its employees. It is clear that expulsion cannot be viewed simply as a refusal to deal, but is a form of pressure which utilizes a special relationship between the parties. The Court of Appeals condemned the activities because of the AMA's tendency to dominate trade:

Except for their size, their prestige, and their otherwise commendable activities, their conduct in the present case differs not at all from that of any other extra-governmental agency which assumes power to challenge alleged wrongdoing by taking the law into its own hands. 82

77190 F. Supp. 241 (S.D.N.Y. 1961).

$78 \mathrm{Id}$. at 244.

${ }^{80} \mathrm{Id}$. at 6.

7928 F.R.D. 2 (D.D.C. 1961).

81317 U.S. 519 (1943).

82 American Medical Ass'n v. United States, 130 F.2d 233. 249 (D.C. Cir. 1942). 
Aside from the $A M A$ case, the legality under the antitrust laws of coercive secondary pressures relying on special relationships does not seem to have been decided. Such activity, as when a school directs its pupils not to patronize a merchant, raises interesting problems. It resembles a secondary refusal to deal, in that pressure is put on a neutral intermediary, and the combination's economic power is extended. On the other hand, the basis of liability in such a case would often have to be not a refusal to deal by the combination, but rather its part in provoking a refusal to deal by someone else.

Liability for a refusal to deal by another party has been established in a number of cases involving the use of persuasion. This result has come about by use of the "conspiracy" concept in a line of cases involving liability for the circulation of blacklists. In Eastern States Retail Lumber Dealers' Ass'n $v$. United States, 83 the Court found that a lumber dealers' association had violated the Sherman Act, although the association itself had not refused to deal with anyone, since the circulation of blacklists by the association was evidence of participation by the association in a conspiracy by which its members boycotted wholesalers on the list:

[W] reported as having made sales to consumers were periodically reported to the other members of the association, the conspiracy to accomplish that which was the natural consequences of such action may be readily inferred. 84

It would appear that a blacklist came to be regarded not merely as evidence of a conspiracy, but as activity illegal in itself. In explaining the holding of Eastern States Lumber in subsequent cases, the Supreme Court said:

[T] hat case establishes that, irrespective of compulsions or even agreement to observe its intimation, the circulation of a list of "unfair dealers," manifestly intended to put the ban upon those whose names appear therein, among an important body of possible customers combined with a view to joint action and in anticipation of such reports, is within the prohibitions of the Sherman Act. ... .85

and:

It is settled by these decisions that such a restraint produced by peaceable persuasion is as much within the prohibition as one accomplished by force or threats of force. . . . s6

By a process of expansion, not only blacklists, but simple persuasion came to be regarded as an antitrust violation. The court in Paramount Pictures, Inc. $v$. United Picture Theatre Owners ${ }^{87}$ held that movie exhibitors had violated the

83234 U.S. 600 (1914).

84 Id. at 612 .

85 Lawlor v. Loewe, 235 U.S. 522, 534 (1915).

86 Duplex Printing Press Co. v. Deering, 254 U.S. 443, 467-68 (1921).

8793 F.2d 714 (3d Cir. 1937). 
antitrust laws merely by attempting to persuade fellow exhibitors to join them in a boycott of producers to obtain better prices and terms:

The Supreme Court, in construing the anti-trust act, made it clear, we think, that combinations or conspiracies constituting a secondary boycott, as we have here, in restraint of trade among the states, are illegal and may be enjoined even though the restraint is produced by means of peaceful persuasion. . . . 88

And in Professional \& Business Men's Life Ins. Co. v. Bankers Life Co., ${ }^{89}$ the court upheld a complaint charging a conspiracy to drive the plaintiff insurance company out of business by printing disparaging newspaper advertisements and handbills:

That the complaint herein charges a per se violation of the Sherman Act, and, therefore, one which . . . Congress has, by legislative fiat, determined to be injurious to the public seems clear to the Court. It charges particularly a conspiracy to drive the plaintiff out of the life insurance business and eliminate its competitive efforts in the sale of life insurance, and that said conspiracy was an attempt to monopolize. 90

In Boerstler v. American Medical Ass'n,91 the court denied a motion to strike part of a complaint alleging that the AMA had conspired with plaintiff's competitor to injure the plaintiff by refusing to grant him the association's seal of approval. The court realized that there was no concerted refusal to deal involved, but only a conspiracy to inhibit plaintiff from marketing his product, yet found that the activity "approximates in result the boycott or blacklist which has been held to violate the Sherman and Clayton Acts."92

Even if a court is unwilling to regard persuasion as a secondary pressure illegal in itself, the holding of the Supreme Court in Interstate Circuit, Inc. $v$. United States ${ }^{93}$ suggests another approach. In that case an illegal conspiracy was found in the absence of an actual agreement, the court stating that "it was enough that, knowing that concerted action was contemplated and invited, the distributors gave their adherence to the scheme and participated in it."94 This would seem to furnish a basis for holding persuasion to be illegal where undertaken by a combination with so much power or prestige that a refusal to deal is a virtually certain result.95 A case in point is Council of Defense $v$.

Ss Id. at 719.

89163 F. Supp. 274 (D. Mont. 1958).

92 Id. at 445.

$90 \mathrm{Id}$. at 285.

93306 U.S. 208 (1939).

9116 F.R.D. 437 (N.D. III. 1954).

$94 \mathrm{Id}$. at 226.

95 The fact situation in Interstate Circuit might be said to be distinguishable from that in such a case as Radiant Burners, in that the latter case does not involve similar actions by the conspirators, but a "chain" type of conspiracy where actions of one party lead to different actions by the other party. Sherman Act cases seem not to have spelled out a "concert of action" theory in the "chain" conspiracy situation. The leading criminal conspiracy case of this type is Direct Sales Co. v. United States, 319 U.S. 703 (1943), where a mail order drug 
International Magazine Co., ${ }^{96}$ where members of a state government commission, found to have been acting outside their official powers, were held to have violated the Sherman Act by inducing newsdealers to cease selling magazines published by William Randolph Hearst, with whose political views the council differed. The newsdealers had been pressured by a publicity campaign in which a list of complying dealers was published in the New Mexico War News with the assertion that the list was "composed of New Mexicans who assay 100 per cent in Americanism. ..."97 In this case, as in many of the cases involving persuasion, it is not clear whether the persuasion is regarded as evidence of participation in a conspiracy, or rather as activity which in itself constitutes an unlawful secondary pressure.

In several antitrust cases the refusal by a testing organization to grant a seal of approval to a product has been asserted to be a form of adverse publicity, and as such an attempt to persuade potential customers to undertake a refusal to buy. In Hughes Tool Co. v. Motion Picture Ass'n,98 the plaintiff complained that the denial of a seal of approval to his movie caused an automatic boycott of the movie by most movie exhibitors. In a dictum, the court said that such activity would be excused by the good purposes of the

company was accused of conspiring with a doctor to violate the narcotics laws by sending him huge quantities of morphine, which the doctor sold illegally. Discussing the difference between selling narcotics and selling more innocent wares, the Court stated: "This difference is important for two purposes. One is for making certain that the seller knows the buyer's intended illegal use. The other is to show that by the sale he intends to further, promote and cooperate in it. This intent, when given effect by overt act, is the gist of conspiracy." Id. at 711 .

In Direct Sales, as in Interstate Circuit, the illegal concert of action consisted of knowledge that concerted action was anticipated and interested participation in it. These were recognized as the elements of illegal conspiracy by Judge Learned Hand in the earlier case of United States v. Falcone, 109 F.2d 579 (2d Cir. 1940), aff'd, 311 U.S. 205 (1940), which involved persons who sold sugar, yeast, and cans to an illegal distilling enterprise: "It is not enough that he does not forego a normally lawful activity, of the fruits of which he knows that others will make an unlawful use; he must in some sense promote their venture himself, make it his own, have a stake in its outcome." Id. at 581. Elaborating on just what kind of interested participation was necessary to prove an illegal conspiracy the court in Direct Sales mentioned discount selling of narcotics in large amounts, disregard of governmental warnings, etc., and concluded: "When the evidence discloses such a system, working in prolonged cooperation with a physician's unlawful purpose to supply him with his stock in trade for his illicit enterprise, there is no legal obstacle to finding that the supplier not only knows and acquiesces, but joins both mind and hand with him to make its accomplishment possible. ... There is informed and interested cooperation, stimulation, instigagation. ..." 319 U.S. at 713. From these cases one might predict that a conspiracy of the "chain" type could be proved in a Sherman Act case by the showing of knowledge of and interested participation in an illegal activity. The meaning of "interested participation" can be said to include the ideas embodied in such phrases as "further, promote, and cooperate," "promote their venture himself, make it his own, have a stake in its outcome," "joins both hand and mind," and "informed and interested cooperation, stimulation, instigation."

96267 Fed. 390 (8th Cir. 1920). This case, although decided before Interstate Circuit, illustrates the possibilities of its application.

97 Id. at 394.

9866 F. Supp. 1006 (S.D.N.Y. 1946). 
association. 99 In Radiant Burners v. Peoples Gas Light \& Coke Co.,100 the plaintiff alleged that the denial of a seal of approval was followed by a refusal by gas utilities to furnish gas to persons who bought unapproved equipment. The Supreme Court considered only the question of whether the refusal to furnish gas was itself an illegal action and did not explore the liability of the American Gas Association for its testing program. In a case such as Radiant Burners, where a boycott is carried out by members of the same association which conducts the testing, the suspicion that the testing program operates in effect as a blacklist will be strong. 101

In a number of cases where it has appeared that a seal of approval program could be used wrongfully to exclude someone from trade, the courts have adopted a standard of fairness, seemingly using a "monopolization" rule such as discussed in part IV. The decision in the Radiant Burners case in the Court of Appeals, for instance, held the complaint to be defective because it did not allege that the tests of the AGA were conducted unfairly as far as the plaintiff's product was concerned.102 In cases involving the grading of lumber by associations of lumbermen, consent decrees provided that the associations could continue the grading activities only if the service were made available without discrimination to members and non-members alike.103 $\mathrm{A}$ produce exchange that licensed "petroleum inspectors" was ordered in a consent decree to adopt uniform standards for the granting of licenses and to grant licenses to any qualified applicant regardless of whether he was a member of the exchange. 104

\section{CONCLUSION}

Perhaps the greatest difficulty in a free society with an unqualified rule against concerted refusals to deal is the seeming inconsistency of such a rule with the society's general encouragement of private voluntary associations formed to achieve a variety of goals. Since labor unions are continually seen to

9916 F.R.D. 437 (N.D. Ill. 1954).

100364 U.S. 656 (1961).

101 In his complaint the plaintiff in Radiant Burners set out the following statement from an American Gas Association brochure entitled "What You Should Know About Your Laboratories: The Approval Plan-Our Theme Song": "Our basic theme song is the Approval Plan. Through voluntary national standards, or as we call them, requirements, the plan seeks to provide consumers with safe gas appliances and accessories of substantial and durable construction which will give satisfactory performance when properly installed. Not only must we be familiar with the theme song, but we must all sing in tune if we would be successful." Record, p. 8.

102273 F.2d 196, 199-200 (7th Cir. 1959).

103 United States v. National Retail Lumber Dealers' Ass'n, 40 F. Supp. 448 (D. Colo. 1942); United States v. National Lumber Mfrs. Ass'n, 1940-43 Trade Cas. 56,123 (D.D.C. 1941); United States v. Western Pine Ass'n, 1940-43 Trade Cas. 56,107 (S.D. Cal. 1941); United States v. Southern Pine Ass'n, 1940-43 Trade Cas. 56,007 (E.D. La. 1940). For a discussion of these cases see Lamb \& Krttelle, Trade Association LaW and Practice 92-94 (1956).

104 United States v. New York Produce Exch., 1959 Trade Cas. 69,395 (S.D.N.Y. 1959). 
exert their economic power, it may seem natural for other associations to do likewise. 105

The doctrine that concerted refusals to deal are per se antitrust violations has been firmly established in cases involving secondary refusals to deal, which mostly involve attempts to injure competitors. In the case of direct refusals to deal, on the other hand, there appear to be some instances where there is still strong authority for applying a "rule of reason"- - or only "duty of fairness" - as in cases involving denial of vital facilities, or refusal of employment.

Groups face two distinct antitrust dangers in the use of secondary pressures other than refusals to deal. The $A M A$ case and the blacklisting cases indicate that if the pressure used is sufficiently coercive to resemble a refusal to deal, the activity will be held illegal by analogy to secondary refusals to deal. Where concert of action is deemed sufficient evidence of a conspiracy, a combination exerting secondary pressure will, by the rules of conspiracy, be judged as if it too were engaged in the direct refusal to deal. Apart from these cases, secondary pressures, although sometimes found to be illegal, will probably be judged according to the "rule of reason" when a group has itself refrained from a refusal to deal.

Although recent cases have greatly broadened the reach of a per se rule in this field, it would seem clear that some refusals to deal will remain lawful unless the courts alter their approach so as to condemn all private use of economic sanctions as attempts to act as an "extra-governmental agency." Absent such a shift in political premises, some scope will remain for application of a rule of reason to antitrust cases involving refusals to deal.

105 The fact that it takes a specific exemption from the antitrust laws to legalize union economic pressures should put non-union organizations on warning that, without such an exemption for themselves, they cannot utilize such pressures. See cases cited note 30 supra and New Negro Alliance v. Sanitary Grocery Co., 303 U.S. 552 (1938), where a consumer boycott aimed at all-white hiring practices was held to be a labor dispute. 